\title{
KAJIAN EKOLOGI PASAK BUMI (Eurycoma longifolia Jack) DAN PEMANFAATAN OLEH MASYARAKAT DI SEKITAR HUTAN LARANGAN ADAT RUMBIO, KABUPATEN KAMPAR PROVINSI RIAU
}

\author{
Sapruddin Hasibuan ${ }^{1}$, Eni Suhesti ${ }^{2}$, Enny Insusanty ${ }^{2}$ \\ ${ }^{1}$ Mahasiswa Fakultas Kehutanan Universitas Lancang Kuning \\ ${ }^{2}$ Staf Pengajar Fakultas Kehutanan Universitas Lancang Kuning \\ Jln. Yos Sudarso Km. 8 Rumbai Pekanbaru Riau \\ Email :sapruddinhasibuan@gmail.com; hesti1170@yahoo.co.id; annovisa@yahoo.com
}

\begin{abstract}
Pasak bumi is one kind of medicinal plants commonly consumed by people and grow in Prohibition of Indigenous Forests Rumbio. Information on the ecological conditions Pasak bumi in Prohibition of Indigenous Forests Rumbio is important known as an indicator of the presence of Pasak bumi, and their population in the forest. The purpose of this study to analyze the ecological conditions Pasak bumi in Prohibition of Indigenous Forests Rumbio, and know how to use Pasak bumu conducted by people around the Prohibition of Indigenous Forests Rumbio. The method used in this study was a survey method, the implementation of the research started from the observation, creating a plot, measurement, and data acquisition. The average temperature in the research location $28,09^{\circ} \mathrm{C}$, average air humidity $85.38 \%$, and the average light intensity of 582.20 lux, type of soil is Red Yellow Podzolic, with a pH of 5.5-6.4. Pasak bumi found in site which it is flat and slopes for $15 \%$, with an altitude of $600-750 \mathrm{~m}$ above sea level. Pasak bumi grown on sloping ground that is not waterlogged. Communities around the Prohibition of Indigenous Forests Rumbio utilize Pasak bumi from the leaves, stems, bark and roots. The perceived benefits of the Pasak bumi by society is to improve blood circulation, eliminate fatigue, malaria drugs, smooth urination, mouth sores, itching disease medicine, a tonic after childbirth and fever.
\end{abstract}

Keywords: ecology, pasak bumi, plant medicine, public knowledge.

\section{PENDAHULUAN}

Hutan Larangan Adat Rumbio merupakan salah satu hutan adat yang masih terjaga kelestariannya. Hutan Larangan Adat Rumbio merupakan salah kawasan hutan yang dikelola oleh masyarakat adat Kenegarian Rumbio, yang berada di empat desa yaitu desa Padang Mutung, Koto Tibun, Pulau Sarak dan Rumbio. Hutan adat Rumbio memiliki luas 570 hektar, memiliki keanekaragaman hayati dan potensi 
tumbuhan obat yang tinggi. Dari hasil penelitian yang telah dilakukan oleh Zulfahmi et al., (2015) diketahui bahwa di kawasan Hutan Larangan Adat Rumbio terdapat tumbuhan yang berkasiat obat seperti Pasak bumi dengan jumlah individu yang rendah. Hal ini terjadi karena adanya pemanenan oleh masyarakat terhadap Pasak bumi untuk keperluan obatobatan sehingga terjadi penurunan jumlah individu sehingga keberadaan pasak bumi di hutan menjadi terancam dalam Hutan Larangan Adat Kenegerian Rumbio.

Penelitian mengenai kajian ekologi tumbuhan obat Pasak bumi di Hutan Larangan adat Rumbio belum pernah dilakukan. Padahal informasi mengenai kondisi ekologi tumbuhan obat, khususnya Pasak bumi di Hutan Larangan Adat Rumbio penting diketahui sebagai indikator keberadaan Pasak bumi dan populasinya di hutan tersebut, yang terus mengalami penurun jumlah dan terancam punah sebagai informasi dasar dalam melakukan tindakan konservasi dan pengayaan jenis Pasak bumi di Hutan Larangan adat Rumbio di masa yang akan datang. Guna menunjang pengadaan bahan tanaman obat melalui pembudidayaan tanaman karena banyaknya permintaan dan peminatan tumbuhan obat Pasak bumi. Berdasarkan alasan tersebut sehingga perlu dilakukan penelitian tentang "Kajian Ekologi Pasak Bumi (Eurycoma longifolia Jack) Dan Pemanfaatan Oleh Masyarakat Di Sekitar Hutan Larangan Adat Rombio, Kabupaten Kampar Provinsi Riau".

Tujuan dari penelitian ini adalah untuk menganalisis kondisi ekologi pasak bumi di Hutan Larangan Adat Rumbio dan untuk mengetahui cara pemanfaatan Pasak bumi (Eurycoma Longifolia Jack) yang dilakukan oleh masyarakat sekitar Hutan Larangan Adat Rumbio.

\section{METODE PENELITIAN}

\section{Tempat dan Waktu}

Penelitian ini akan dilakukan di Hutan Larangan Adat Rumbio Kabupaten Kampar Propinsi Riau. Penelitian ini dilaksanakan selama 4 bulan, yaitu pada Bulan Februari-Mei 2016

\section{Alat dan Bahan}

Alat yang digunakan dalam penelitian ini adalah meteran, kompas, kamera digital, tali, GPS, haga meter, phi band, hygrometer, thermometer, parang, penggaris dan alat tulis. 
Sedangkan bahan yang digunakan adalah plastik bening, patok/kayu, tally sheet pengukuran tingkat pertumbuhan (semai, pancang, tiang, pohon), dan kuisioner.

\section{Metode Penelitian}

Metode yang digunakan dalam penelitian ini adalah metode survey, pelaksanaan penelitiannya dimulai dari observasi, pembuatan plot, pengamatan, dan pengambilan data.

\section{Observasi}

Dalam penelitian ini, peneliti akan membawa seorang dukun atau tabib dan seorang masyarakat lokal yang sering menggunakan dan mengambil Pasak bumi yang terdapat didalam kawasan Hutan Larangan Adat Rumbio, sehingga dapat membantu peneliti dilapangan.

\section{Wawancara}

Dalam penelitian ini, responden wawancara berjumlah 30 orang masyarakat sekitar Hutan Larangan Adat Rombio dan 2 orang tabib. Penentuan sampel dilakukan dengan cara purposive sampling, berdasarkan kriteria umur, dan tempat tinggalnya. Wawancara dilakukan sewaktu melakukan pengambilan data dilokasi penelitian yang bertujuan untuk mengetahui cara pemanfaatan dan manfaat pasak bumi yang dilakukan oleh masyarakat sekitar Hutan Larangan Adat Rumbio.

\section{Pembuatan Plot}

Untuk melihat adaptasi, asosiasi dan vegetasi penyusun habitat antara tumbuhan Pasak bumi dengan tumbuhan lainnya, maka dibuat plot pengamatan. Ukuran plot pengamatan pada penelitian ini adalah $50 \mathrm{~m} \times 20 \mathrm{~m}$, kemudian dibagi menjadi 10 jalur rintis dengan jarak antar garis rintis 100m. Sehingga dalam satu jalur rintisan terdapat 10 petak, jumlah semua petak dari 10 jalur rintisan berjumlah 100 petak. Luas plot dalam satu jalur rintis adalah 0.4 ha. Penentuan plot dilakukan secara purposive sampling, yaitu berdasarkan kriteria banyaknya jumlah pasak bumi yang terdapat di plot tersebut.

\section{Parameter Pengamatan}

\section{Karakteristik Fisik}

Karakteristik fisik yang diamati adalah suhu, kelembaban udara, curah hujan.

\section{Suhu dan Kelembaban Udara}

Pengukuran parameter meliputi suhu dan kelembaban udara yang dilakukan pada waktu dan titik lokasi yang bersamaan. Pengukuran suhu, kelembaban udara dilakukan 3 kali pengukuran dalam sehari dengan waktu 
yang berbeda, yaitu: pagi pukul 07.00 08.00 wib, siang pukul $12.00-13.00$ wib, dan sore pukul 17.00 - 18.00 wib selama 2 minggu. Dengan menggunakan alat thermometer untuk mengukur suhu, sedangkan alat yang digunakan untuk mengukur kelembaban udara menggunakan hygrometer.

\section{Curah Hujan}

Untuk data curah hujan dan jumlah hari hujan selama 2 tahun terakhir dicatat dari stasiun Meteorologi terdekat atau daerah yang mewakili lokasi penelitian.

\section{Data Fisiologi}

Data fisiologi yang diamati adalah ketinggian tempat dari permukaan laut, $\mathrm{pH}$ tanah, jenis tanah, warnah tanah, kandungan unsur hara tanah serta ketebalan serasah.

1. Data ketinggian tempat dari permukaan laut dapat diminta dari kantor pengelola Hutan Larangan Adat Rumbio.

2. Untuk mengetahui $\mathrm{pH}$ tanah, jenis tanah, kandungan unsur hara tanah, dan warna tanah dilakukan analisis Laboratorium. Contoh tanah diambil dari plot pengamatan dengan cara menggali tanah dengan parang sampai kedalaman $30 \mathrm{~cm}$ ambil segenggam tanah, ambil dari 3 plot pengamatan sebagai sampel, masukkan dalam plastik bening untuk diuji di laboratorium.

3. Ketebalan serasah diukur pada setiap plot pengamatan dengan cara menggali, kemudian diukur ketebalannya dengan menggunakan penggaris.

\section{Metode Pengumpulan Data}

Pengumpulan data yang diperoleh dalam penelitian ini adalah data primer dan data sekunder.

\section{Data Primer}

Data primer diperoleh melalui pengamatan langsung dilapangan, seperti: suhu, kelembaban udara, $\mathrm{pH}$ tanah, jenis tanah, warna tanah, kandungan unsur hara tanah, ketebalan serasah, dan pemanfaatan Pasak bumi oleh masyarakat disekitar Hutan Larangan Adat Rombio.

\section{Data Sekunder}

Data sekunder dalam penelitian ini adalah kondisi umum lokasi penelitian, peta, data curah hujan. Serta hasil penelitian yang telah dilakukan baik skripsi maupun jurnal yang berkaitan dengan judul yang akan diteliti sebagai acuan dalam melakukan penelitian ini.

\section{Analisis Data}


Setelah pengumpulan data dilakukan, selanjutnya dianalisis secara deskriptif. Adapun analisis datanya sebagai berikut:

\section{Analisis Vegetasi}

Analisis vegetasi adalah cara untuk mempelajari komposisi jenis dan struktur vegetasi dalam suatu ekosistem. Cara pengumpulan data vegetasi di Hutan Larangan Adat Rombio diambil menggunakan metode jalur berpetak. Beberapa data diperoleh dari lapangan dikumpulkan dan dihitung untuk menyatakan beberapa variabel antara lain (Ningsih, 2009):

Indeks nilai penting (INP) digunakan untuk menentukan dominasi dari suatu jenis vegetasi. Indeks nilai penting didapat dari perhitungan sebagai berikut:

Untuk tingkat semai dan pancang, $\mathrm{INP}=\mathrm{KR}+\mathrm{FR}$

Untuk tingkat tiang dan pohon, $\mathrm{INP}=\mathrm{KR}+\mathrm{FR}+\mathrm{DR}$

Kerapatan relatif, frekuensi relatif, dan dominasi relatif dapat dihitung sebagai berikut:

a. Kerapatan suatu jenis $(\mathrm{K})$, dihitung rumus :

$$
K=\frac{\text { Jumlah individu suatu jenis }}{\text { Luas petak contoh }}
$$

b. Kerapatan Relatif (KR) suatu jenis, dihitung dengan rumus :

$$
K R
$$

$$
=\frac{\text { Kerapatan suatu Jenis }}{\text { Kerapatan seluruh jenis }} \times 100 \%
$$

c. Frekuensi (F) suatu jenis, dihitung dengan rumus:

$$
\begin{aligned}
& F \\
& =\frac{\text { Jumlah petak ditemukan suatu jenis }}{\text { Jumlah seluruh petak contoh }}
\end{aligned}
$$

d. Frekuensi Relatif (FR) Suatu jenis, dihitung dengan rumus:

$$
\begin{aligned}
& \text { FR } \\
& =\frac{\text { Frekuensi suatu jenis }}{\text { Frekuensi seluruh jenis }} \times 100 \%
\end{aligned}
$$

e. Dominasi (D) suatu jenis, dihitung dengan rumus :

$$
D=\frac{\text { Luas bidang dasar suatu jenis }}{\text { luas petak contoh }}
$$

f. Dominasi relatif (DR) Suatu jenis, dihitung dengan rumus:

$$
D R=\frac{\text { Dominasi suatu jenis }}{\text { Dominasi seluruh jenis }} \times 100 \%
$$

HASIL DAN PEMBAHASAN Kondisi Ekologi Pasak Bumi di Hutan Larangan Adat Rumbio Karakteristik Fisik 
Suhu, Kelembaban Udara, dan dilakukan selama 2 minggu atau 14 kali Intensitas Cahaya

Karakteristik fisik yang dilakukan pengukuran secara periodik yang pengukuran terhadap suhu, kelembaban udara dan intensitas cahaya dapat dilihat pada tabel 1 berikut ini.

Tabel 1. Karakteristik fisik

\begin{tabular}{llcccc}
\hline \multirow{2}{*}{ No } & \multirow{2}{*}{ Karakteristik Fisik } & \multicolumn{3}{c}{ Waktu pengukuran } & Nilai Rata-rata \\
\cline { 3 - 4 } & & Pagi & Siang & Sore & Pengukuran \\
\hline 1 & Suhu $\left({ }^{\circ} \mathrm{C}\right)$ & 26,06 & 29,39 & 28,81 & 28,09 \\
\hline 2 & Kelembaban Udara (\%) & 87,50 & 83,14 & 85,50 & 85,38 \\
\hline 3 & Intensitas Cahaya (lux) & 410,50 & 833,71 & 502,40 & 582,20 \\
\hline & Sumber: Data olahan, 2016 & & & &
\end{tabular}

Hasil penelitian menunjukkan bahwa suhu rata-rata di Hutan Larangan Adat Rumbio $28,09^{\circ} \mathrm{C}$ dengan kelembaban udara rata-rata $85,38 \%$, dan intensitas cahaya rata-rata 582,20 lux. Hasil penelitian tersebut juga menyatakan bahwa tempat tumbuh yang disukai oleh Pasak bumi adalah pada tanah miring yang tidak tergenang air. Hasil penelitian yang telah dilakukan di Hutan Larangan Adat Rumbio berbeda dengan hasil penelitian Lesmana (2005) dalam Kartikawati (2014) yang dilakukan di hutan Pikul Desa Sahan Kecamatan Seluas, Kabupaten Bengkayang. Hasilnya menunjukkan rata-rata suhu harian $25.07^{\circ} \mathrm{C}$, rata-rata kelembaban udara $91.49 \%$, dan intensitas cahaya rata-rata $0.84 \mathrm{Klx}$. Hasil penelitian Nuryamin (2000) dalam (Subiandono, 2006), Pasak bumi tumbuh pada temperatur $25^{\circ} \mathrm{C}$ dengan kelembaban udara $86 \%$. Berbeda juga dengan hasil penelitian yang dilakukan oleh Ginting (2010), menunjukkan bahwa kondisi ekologi Pasak bumi dengan komponen tanah terdiri atas pasir, debu dan liat, suhu udara rata-rata $24.10^{\circ} \mathrm{C}$, kelembaban udara rata-rata $90.8 \%$, dan intensitas cahaya rata-rata $113.6 \times 10$ lux.

\section{Curah Hujan}

Data curah hujan di daerah sekitar Hutan Larangan Adat Rumbio diperoleh dari Stasiun BMKG Simpang Tiga, dimana curah hujan rata-rata tahunan pada tahun 2015 adalah 2236 $\mathrm{mm} /$ tahun. Jumlah hari hujan keseluruhan adalah 256 hari/tahun (Stasiun BMKG Simpang Tiga, 2016). Kriteria distribusi curah hujan bulanan: 
rendah $=0-100 \mathrm{~mm}$, sedang $=101-300$ $\mathrm{mm}$, tinggi $>300 \mathrm{~mm}$ (Boer, 2006). Curah hujan bulanan di Hutan Larangan Adat Rumbio adalah $186.33 \mathrm{~mm} / \mathrm{bulan}$ termasuk kategori sedang. Kondisi curah hujan di sekitar Hutan Larangan Adat Rumbio cocok untuk habitat pasak bumi.

\section{Ketinggian Tempat}

Data ketinggian tempat Hutan Larangan Adat Rumbio diperoleh dari Yayasan Pelopor Sehati, dimana ketinggian tempatnya adalah $1.200 \mathrm{~m}$ dpl. Hasil penelitian yang telah dilakukan, Pasak bumi (Eurycoma longifolia Jack) ditemukan didaerah datar dan berlereng dengan kemiringan $15 \%$, dengan ketinggian tempat 600 $750 \mathrm{~m}$ dpl. Hasil penelitian tersebut juga menyatakan bahwa tempat tumbuh yang disukai oleh Pasak bumi pada tanah miring yang tidak tergenang air (rawa). Hasil penelitian Ginting (2010) di Hutan Bukit Lawang menunjukkan pasak bumi banyak ditemukan pada rentang ketinggian antara 500-600 m dpl pada kelerengan $>25 \%$. Pasak bumi dapat dijumpai pada daerah-daerah pungggung bukit atau pematang dan daerah berlereng dengan ketinggian tempat $1000 \mathrm{~m}$ dari permukaan laut
(Nuryamin, 2000) dalam (Subiandono, 2006).

\section{pH, Jenis, dan Warna Tanah}

Dari hasil uji laboratorium yang telah dilakukan jenis tanah di Hutan Larangan Adat Rumbio adalah Podsolik Merah Kuning berwarna kuning-kecoklatan, dengan $\mathrm{pH}$ tanah 5.5-6.4. Ketebalan serasah di Hutan Larangan Adat Rumbio cukup tinggi yaitu $12-27 \mathrm{~cm}$. Masriadi (2011) menyatakan bahwa Hutan Larangan Adat Kenegarian Rumbio memiliki tanah podsolik yang relatif kurang subur, dan kondisi ini cocok untuk pertumbuhan dan perkembangan Pasak bumi. Hadiah (2000) menyatakan bahwa pasak bumi tumbuh dengan baik pada tanah masam, berpasir, dan miskin unsur hara. Hasil penelitian yang dilakukan oleh Ginting (2010) di sekitar Hutan Bukit Lawang, $\mathrm{pH}$ tanah rata- rata adalah 6.4. Berdasarkan hasil penelitian yang telah dilakukan kondisi Hutan Larangan Adat Rumbio cocok untuk habitat Pasak bumi.

Habitat, Adaptasi, Asosiasi dan Vegetasi Penyusun Habitat Pasak Bumi (Eurycoma longifolia Jack) Habitat Pasak Bumi (Eurycoma longifolia Jack) 
Tidak semua wilayah Hutan Larangan Adat Rumbio dijumpai Pasak bumi (Eurycoma Longifolia Jack). Karena kondisi Hutan Larangan Adat Rumbio berbeda-beda. Pasak bumi (Eurycoma Longifolia Jack) ditemukan sampai ketinggian tempat 600-750 m dari permukaan laut. Pasak bumi dapat dijumpai pada daerah pungggung bukit atau pematang, daerah datar dan berlereng dengan kemiringan 15\%, tempat tumbuh yang disukai oleh Pasak bumi pada tanah miring yang tidak tergenang air (rawa). Habitat pasak bumi merupakan hutan tropis dengan curah hujan yang cukup tinggi dan tanahnya tidak pernah tergenang air, datar tetapi lebih disukai kondisi tanah yang miring, aerasi baik atau banyak mengandung pasir. Pada tingkat semai, tumbuhan ini banyak dijumpai mengelompok di bawah tajuk hutan. Tumbuhan muda tidak menyukai cahaya langsung yang terlalu banyak, tetapi memerlukan cahaya langsung sejak tumbuhan memasuki tingkat pohon.

\section{Adaptasi dan Asosiasi Pasak Bumi (Eurycoma longifolia Jack)}

Hasil penelitian yang telah dilakukan menunjukkan bahwa penyebaran Pasak bumi (Eurycoma longifolia Jack) di
Hutan Larangan Adat Rumbio secara mengelompok. Setiap plot pengamatan Pasak bumi ditemukan secara mengelompok, biasanya ditemukan 2-3 individu dalam satu petak ukur. Pasak bumi (Eurycoma longifolia Jack) di Hutan Larangan Adat Rumbio selalu berdampingan, selalu ada/ hadir bersama-sama dengan Ribu-ribu (Anisophyllea disticha Jack), Meranti kunyit (Shorea parvifolia) dan Pagarpagar (Jatropha curcas L). Adanya interaksi antar spesies akan menghasilkan asosiasi yang memilih untuk hidup di habitat yang sama, mempunyai daya penolakan atau daya tarik atau bahkan tidak berinteraksi sama sekali (Khow, 2008) dalam (Paillin, 2009).

Berdasarkan hasil penelitian Zulfahmi (2015) di Hutan Larangan Adat Rumbio, menunjukkan bahwa pola penyebaran Pasak Bumi (Eurycoma Longifolia Jack) memiliki pola penyebaran mengelompok dengan nilai indeks morisita $>1$, hal ini mengindikasikan rendahnya predator benih dan semai di areal ini, sesuai dengan yang disampaikan Okuda et al. (1997) bahwa penyebaran spesies mengelompok disebabkan oleh rendahnya predator benih dan semai 
serta rendahnya tingkat mortaliti spesies. Pola penyebaran Pasak bumi yang mengelompok ini berkaitan dengan sistem reproduksinya melalui biji. Pasak bumi memiliki biji yang relatif berat sehingga benihnya jatuh dan anakan tumbuh tidak jauh dari pohon induknya. Hasil penelitian Rifai (1975) diacu dalam Kartika (2014), menunjukkan bahwa pola sebaran Pasak bumi mengelompok dan berasosiasi dengan Kempas (Koompassia malacensis). Hasil penelitian Lesmana (2005) diacu dalam Kartika (2014), Pola persebaran pasak bumi mengelompok dan berasosiasi dengan meranti putih (Shorea lemellata) dan meranti merah (Shorea leprosulla).

\section{Vegetasi Penyusun Habitat Pasak}

\section{Bumi (Eurycoma longifolia Jack)}

Hutan Larangan Adat Rumbio adalah hutan dataran rendah dan tipe hutan hujan tropis.Hal ini dapat dilihat berdasarkan ciri-ciri hutan hujan tropis yaitu iklim basah, tanah kering, mempunyai kelembaban udara yang tinggi, dan didominasi oleh vegetasi dari jenis Dipterocarpaceae. Berdasarkan tingkat pertumbuhannya, ada beberapa kategori vegetasi yang diidentifikasi pada lokasi penelitian, yaitu: semai, pancang, tiang dan pohon. Hasil analisis vegetasinya disajikan sebagai berikut:

\section{Tingkat Semai}

Hasil analisis vegetasi pada tingkat semai menunjukkan bahwa kerapatan tertinggi adalah pasak bumi dengan nilai 3,000 (ni/ha). Hal ini menunjukkan bahwa jenis yang paling melimpah pada tingkat semai adalah pasak bumi.

Frekuensi relatif menunjukkan penyebaran suatu jenis pada suatu petak contoh. Untuk penyebaran individu menunjukkan bahwa jenis yang paling menyebar (jenis yang sering ditemukan) adalah pasak bumi sebesar $17.86 \%$. Berdasarkan indeks nilai pentingnya, jenis yang paling dominan pada komunitas petak contoh untuk tingkat semai adalah pasak bumi, dimana indeks nilai pentingnya merupakan yang terbesar, yaitu $38.36 \%$.

\section{Tingkat Pancang}

Hasil analisis vegetasi menunjukkan bahwa kerapatan tertinggi pada tingkat pancang adalah kandis dan kelat dengan nilai 125 (ni/ha). Hal ini menunjukkan bahwa jenis yang paling melimpah pada tingkat pancang adalah kandis dan kelat. Penyebaran jenis tanaman yang paling menyebar (jenis yang sering ditemukan) berdasarkan 
nilai frekuensi relatif adalah kandis dan kelat sebesar 11.36\%. Berdasarkan indeks nilai pentingnya, jenis yang paling dominan pada komunitas petak contoh untuk tingkat pancang adalah kandis dan kelat, dimana indeks nilai pentingnya merupakan yang terbesar, yaitu $23.13 \%$. Untuk keberadaan tanaman pasak bumi pada tingkat pancang ini tidak ditemukan.

\section{Tingkat Tiang}

Kerapatan tertinggi pada tingkat tiang adalah medang dengan nilai 75 (ni/ha) berdasarkan hasil analisis vegetasi yang telah dilakukan. Hal ini menunjukkan bahwa jenis yang paling melimpah pada tingkat tiang adalah medang. Frekuensi relatif menunjukkan penyebaran suatu jenis menunjukkan bahwa jenis yang paling menyebar (jenis yang sering ditemukan) adalah medang sebesar 12.50\%. Berdasarkan indeks nilai pentingnya, jenis yang paling dominan pada komunitas petak contoh untuk tingkat tiang adalah medang, dimana indeks nilai pentingnya merupakan yang terbesar, yaitu 31.64\%. Tanaman pasak bumi dijumpai 1 individu dengan kerapatan nilai 25(ni/ha).

\section{Tingkat Pohon}

Pada tingkat pohon hasil analisis vegetasi menunjukkan bahwa kerapatan tertinggi pada adalah medang dengan nilai 14.29 (ni/ha). Hal menunjukkan bahwa jenis yang paling melimpah pada tingkat pohon adalah medang. Frekuensi relatif menunjukkan penyebaran suatu jenis menunjukkan bahwa jenis yang paling menyebar (jenis yang sering ditemukan) adalah medang sebesar $17.29 \%$. Dilihat dari besarnya nilai frekuensi relatifnya, vegetasi di Hutan Larangan Adat Rumbio pada tingkat pohon termasuk rendah, yaitu $17.29 \%$. Hal ini sesuai dengan pernyataan Odum (1993) dalam Zamri (2014), menyatakan bahwa nilai frekuensi relative suatu tumbuhan dikatakan rendah apabila nilainya 0$33 \%$, sedang 33-66\%, dan tinggi 66$100 \%$. Berdasarkan indeks nilai pentingnya, jenis yang paling dominan pada komunitas petak contoh untuk tingkat pohon adalah medang, dimana indeks nilai pentingnya merupakan yang terbesar, yaitu: $41.07 \%$.

Untuk keberadaan dan penyebaran serta Indeks Nilai Penting (INP) Pasak bumi pada tiap tingkat pertumbuhan dapat dilihat pada Tabel 2 berikut

ini. 
Tabel 2. Indeks Nilai Penting Pasak Bumi pada beberapa tingkat pertumbuhan

\begin{tabular}{ccccccccc}
\hline No & Tingkat & $\sum$ Individu & $\sum$ Petak & $\begin{array}{c}\text { K } \\
(\mathbf{n i} / \mathbf{h a})\end{array}$ & KR (\%) & FR (\%) & DR(\%) & $\begin{array}{c}\text { INP } \\
(\%)\end{array}$ \\
\hline 1 & Semai & 120 & 73 & 3,000 & 17.86 & 20.51 & - & 38.36 \\
\hline 2 & Pancang & - & - & - & - & - & - & - \\
\hline 3 & Tiang & 1 & 1 & 25 & 4 & 4.17 & 2.38 & 10.55 \\
\hline 4 & Pohon & - & - & - & - & - & - & - \\
\hline & Sumber. Data olahan, 2016 & & & & & &
\end{tabular}

Dari hasil analisis vegetasi semua tingkat pertumbuhan menunjukkan bahwa pasak bumi tingkatan semai lebih mendominasi habitat tumbuhan dilokasi penelitian dengan dibanding pasak bumi tingkatan pancang, tiang dan pohon dimana berdasarkan tabel 2 dapat dilihat jumlah semai yang dijumpai mencapai 120 individu dan pada tingkat tiang sebanyak 1 individu. Hal ini terjadi karena adanya pemanenan oleh masyarakat terhadap pasak bumi ukuran pancang dan tiang untuk keperluan obat-obatan sehingga terjadi penurunan jumlah individu dalam hutan Larangan Adat Kenegerian Rumbio. Ditambah lagi pertumbuhan pasak bumi yang tergolong lambat, hal ini terkait dengan pasak bumi sebagai tanaman berkayu. Sampai saat ini belum diketahui berapa tingkat pertumbuhan pasak bumi dalam setahun dan mungkin diperlukan penelitian lanjutan terkait dengan itu.

Kerapatan pasak bumi dalam studi termasuk kategori rendah dan lebih banyak pasak bumi ukuran semai yang tersisa, hal ini akan berpengaruh kepada perkembangbiakan pasak bumi dan organisme lain. Menurut Lazuriaga et al. (2006) bahwa ukuran tanaman dalam suatu populasi akan mempengaruhi reproduksi tanaman, seperti perilaku pollinator, tingkat perkawinan dan jumlah biji yang terbentuk. Tanaman pasak bumi dalam ukuran semai tentu belum mampu bereproduksi dengan baik sehingga produksi benih pasak bumi akan terganggu dan polinator tertentu akan terpaksa mencari bunga tanaman pengganti untuk kelangsungan hidupnya. Oleh karena itu, berbagai upaya pengamanan pasak bumi di Hutan Larangan Adat Rumbio perlu menjadi perhatian pihak pengelola hutan dalam hal ini adalah pemangku adat Kenegarian Rumbio. Upaya yang dapat dilakukan untuk penyelamatan pasak bumi tersebut adalah:

1. Melarang pengambilan pasak bumi oleh masyarakat di Hutan Larangan Adat Rumbio. 
2. Melakukan penanaman pengayaan pasak bumi (replanting) di Hutan Larangan Rumbio sehingga kelimpahan pasak bumi meningkat kembali.

3. Memberikan sanksi atau penegakan hukum adat bagi masyarakat yang mengambil pasak bumi secara illegal.

Cara Pemanfaatan dan Pengolahan Pasak Bumi (Eurycoma longifolia Jack) yang Dilakukan oleh Masyarakat Sekitar Hutan Larangan Adat Rombio

Berdasarkan hasil wawancara terhadap 30 orang responden masyarakat di sekitar Hutan Larangan Adat Rumbio memanfaatkan pasak bumi sebagai obat tradisional mulai dari daun, batang, kulit, dan akar. Masyarakat di sekitar hutan Larangan Adat Rumbio yang menyatakan sering memanfaatkan pasak bumi sebagai obat berjumlah 24 orang, sedangkan 4 orang lainnya menyatakan jarang memanfaatkan pasak bumi. Sumber informasi pemanfaatannya berasal dari turuntemurun dari ninik mamak. Masyarakat mengaku sudah lama mengkonsumsi pasak bumi, ada yang menjawab 2 tahun bahkan ada yang sudah 30 tahun mengkonsumsi pasak bumi tersebut.

Manfaat pasak bumi yang dirasakan oleh masyarakat adalah akar pasak bumi bisa digunakan untuk melancarkan peredaran darah, menghilangkan rasa sakit, rasa capek, obat malaria, dan melancarkan buang air kecil, diabetes, obat kuat, obat diare. Kulit dan batangnya digunakan untuk mengobati demam, sariawan, serta sebagai tonik setelah melahirkan. Daunnya digunakan untuk mengobati penyakit gatal. Cara pemanfaatan bagian tumbuhan tersebut sebagian besar dengan cara direbus selain itu ada pula dengan cara meremas bagian tumbuhan, dan meramu. Cara pemanfaatan akar pasak bumi untuk menghilangkan rasa capek dan melancarkan peredaran darah yang dilakukan oleh masyarakat sebagai berikut: Akar diiris, kemudian rebus lalu air rebusan diminum $1 / 2$ gelas selama 2 $x$ dalam semingggu. Cara pemanfaatan akar pasak bumi untuk obat kuat sebagai berikut: Akar diiris, kemudian rebus lalu air rebusan diminum 1 gelas selama $3 \mathrm{x}$ dalam semingggu. Cara pemanfaatan kulit dan batangnya untuk mengobati demam dan sariawan sebagai berikut: kulit atau batang di potong-potong, kemudian rebus lalu air rebusan diminum $1 / 2$ gelas selama demam dan sariawan. Cara pemanfaatan daunnya untuk mengobati penyakit gatal, sebagai berikut: remas 
atau giling daun pasak bumi secukupnya sampai halus kemudian oleskan ke kulit yang gatal, lakukan $2 \times$ sehari.

Dari hasil wawancara terhadap responden ternyata masyarakat masih memanfaatkan pasak bumi dan tumbuhan obat lainnya yang ada di Hutan Larangan Adat Rumbio, dan upaya penanaman pasak bumi dipekarangan rumah yang menjawab belum dilakukan oleh masyarakat berjumlah 27 orang, sedangkan yang sudah membudidayakan pasak bumi berjumlah 3 orang. Perhatian dari pemerintah terhadap tanaman obat belum dikembangkan dan belum ada dana yang diberikan. Harapan masyarakat untuk pengembangan tanaman obat ini seharusnya pemerintah turut serta dalam pengembangan dan memberikan dana serta penyuluhan supaya masyarakat dapat mengembangkan tanaman tersebut dan menanamnya di areal pekarangan rumah, supaya masyarakat tidak hanya memanfaatkan tumbuhan obat dari hutan sehingga tidak punah.

Pasak bumi merupakan salah satu dari 283 bahan baku tumbuhan obat yang telah diregistrasi oleh Badan POM yang masih ditambang dari hutan. Volume dan kualitas pasak bumi sebagai bahan baku tumbuhan obat sangat tergantung pada ketersediaan stok pasak bumi dan musim. Menurut Purwandari (2000) serapan tumbuhan obat dipengaruhi oleh beberapa faktor, yaitu perkembangan industri, kebijakan pemerintah, harga serta kondisi stok di alam. Khasiat pasak bumi yang sudah terbukti dari berbagai hasil penelitian mendorong permintaan pasak bumi di pasar meningkat. Melihat nilai ekonomi pasak bumi yang cukup tinggi, maka penting untuk segera dilakukan jaminan pengelolaan keberlanjutan pasak bumi. Selama ini pemungutan hanya mengandalkan pasak bumi dari alam, bukan dari tanaman hasil budidaya. Pemanfaatan pada bagian akar secara otomatis akan mematikan pohon pasak bumi karena teknik pemungutan dilakukan dengan cara mencabut akarnya. Perilaku fisiologis waktu berbunga yang tidak menentu dan proses pertumbuhan yang lambat membuat pasak bumi yang memiliki status langka akan terancam kelestariannya dan semakin jarang ditemui (Hussein 2005). Hal ini diperkuat dengan hasil survei di Kalimantan Tengah pada tahun 2004 yang menunjukkan populasi pasak bumi 
di hutan sudah sangat terbatas jumlahnya (Raharjo 2010).

\section{KESIMPULAN DAN SARAN}

\section{Kesimpulan}

Dari hasil pembahasan diatas dapat disimpulkan:

1. Suhu rata-rata lokasi penelitian $28,09^{\circ} \mathrm{C}$, kelembaban udara rata-rata $85,38 \%$, dan intensitas cahaya ratarata 582,20 lux, jenis tanah adalah Podsolik Merah Kuning berwarna kuning-kecoklatan, dengan $\mathrm{pH}$ 5.56.4. Ketebalan serasah cukup tinggi yaitu 12-27 cm. Pasak bumi (Eurycoma longifolia Jack) ditemukan didaerah datar dan berlereng dengan kemiringan 15\%, dengan ketinggian tempat 600-750m dpl. Tempat tumbuh yang disukai Pasak bumi (Eurycoma longifolia Jack) pada tanah miring yang tidak tergenang air (rawa). Kondisi Hutan Laranga Adat Rumbio cocok untuk habitat Pasak bumi. Pola penyebaran Pasak Bumi (Eurycoma longifolia Jack)memiliki pola penyebaran mengelompok, selalu berdampingan, selalu ada/ hadir bersama-sama dengan Ribu-ribu, Meranti kunyit dan Pagar-pagar.
2. Masyarakat disekitar Hutan Larangan Adat Rumbio memanfaatkan pasak bumi sebagai obat tradisional mulai dari daun, batang, kulit, dan akar. Cara menggunakan bagian tumbuhan tersebut sebagian besar dengan cara direbus selain itu ada pula dengan cara meremas bagian tumbuhan, dan meramu. Manfaat pasak bumi yang dirasakan masyarakat adalah untuk melancarkan peredaran darah, menghilangkan rasa sakit, rasa capek, obat sakit perut, obat malaria, dan melancarkan buang air kecil, sariawan,obat penyakit gatal, tonik setelah melahirkan dan demam.

\section{Saran}

Saran yang dapat disampaikan yaitu:

1. Perlu adanya upaya konservasi untuk pengembangan pasak bumi di Hutan Larangan Adat Rumbio, supaya terhindar dari kepunahan.

2. Penelitian dari aspek-aspek yang lain baik silvikultur maupun teknologi ekstraksi sangat diperlukan baik sebagai landasan dalam strategi konservasi, budidaya, maupun untuk tujuan komersial.

\section{DAFTAR PUSTAKA}


Boer. 2006.Kondisi Iklim di Kupang. [Jurnal]. Kupang. Diakses pada hari selasa, 2 agustus 2016 pukul 20.33 wib.

Ginting, A. 2010.Kajian Ekologi Pasak Bumi (Eurycoma longifolia Jack) Dan Pemanfaatan Oleh Masyarakat Di Sekitar Hutan Bukit Lawang.[Tesis]. Medan. Program Studi Magister IImu Biologi. Universitas Sumatera Utara.

Hadiah, J.T. 2000. Eurycoma longifolia Jack (Pasak Bumi).Eksplorasi 2(4): 6 .

Hussein S. 2005. Multiple shoot formation of important tropical mediclinal plant, Eurycomalongifolia Jack. J. Biotechnol 22: 349-351.

Kartikawati, S.M. 2014. Konservasi Pasak Bumi (Eurycoma longifolia Jack) Ditinjau Dari Aspek Kelembagaan Tata Niaga.[Tesis]. Bogor. Sekolah Pascasarjana. Institut Pertanian Bogor.

Lazuriaga, A.L., Escudero, A., Albert, M.J. and Gimenez-Binavides, L. 2006. Population structure effect on reproduction of a rare plant: beyond population size effect. Canadian Journal of Botany, 84: 1371-1379.

Masriadi. 2011. Profil Hutan Larangan Adat dan Kearifan lingkungan Masyarakat Adat Kenegrian Rumbio. Pekanbaru (unpublihsed).

Nengsih, H. 2009. Struktur Komunitas Pohon Pada Tipe Lahan Yang Dominan Di Desa Lubuk Beringin, Kabupaten Bungo, Jambi.
[Skripsi]. Bandung. Program Studi Biologi Sekolah IImu Dan Teknologi Hayati Institut Teknologi Bandung.

Paillin, J.B. 2009.Asosiasi Interspesies lamun di Perairan Ketapang kabupaten Seram Bagian Barat.[Jurnal Triton Vol. 5 No.2].Ambon. Jurusan Menajemen Sumberdaya Perikanan. Fakultas Perikanan dan Kelautan. Universitas Pattimura.

Purwandari, SS. 2000. Studi serapan obat sebagai bahan baku pada berbagai industri obat tradisional Indonesia. [Tesis]. Bogor (ID): Sekolah Pasca sarjana IPB.

Rahardjo, M. 2010. Tanaman obat afrodisiak. Warta Penelitian dan Pengembangan Tanaman. Badan Penelitian dan Pengembangan Pertanian, Pusat Penelitian dan Pengembangan Perkebunan. 16(2):8-12.

Subiandono, et al,.2006. Kajian Ekologi dan Potensi Pasak Bumi (Eurycoma longifolia Jack.) di Kelompok Hutan Sungai MannaSungai Nasal, Bengkulu.[Buletin Plasma Nuftah]. Bogor. Pusat Litbang Hutan dan Konservasi Alam, Bogor.

Zulfahmi, et al,. 2015. Kepadatan dan Pola Penyebaran Pasak Bumi (Eurycoma longifolia Jack) Di Zona Alaman Kuyang, Hutan Larangan Adat Kenegarian Rumbio. [Jurnal Agroteknologi]. Riau.UIN Sultan Syarif Kasim Riau Kampus Raja Ali Haji. 